\title{
卫
}

\section{Analysis of shipments of cut tulips in 12 reefer containers}

Author: Leo Lukasse

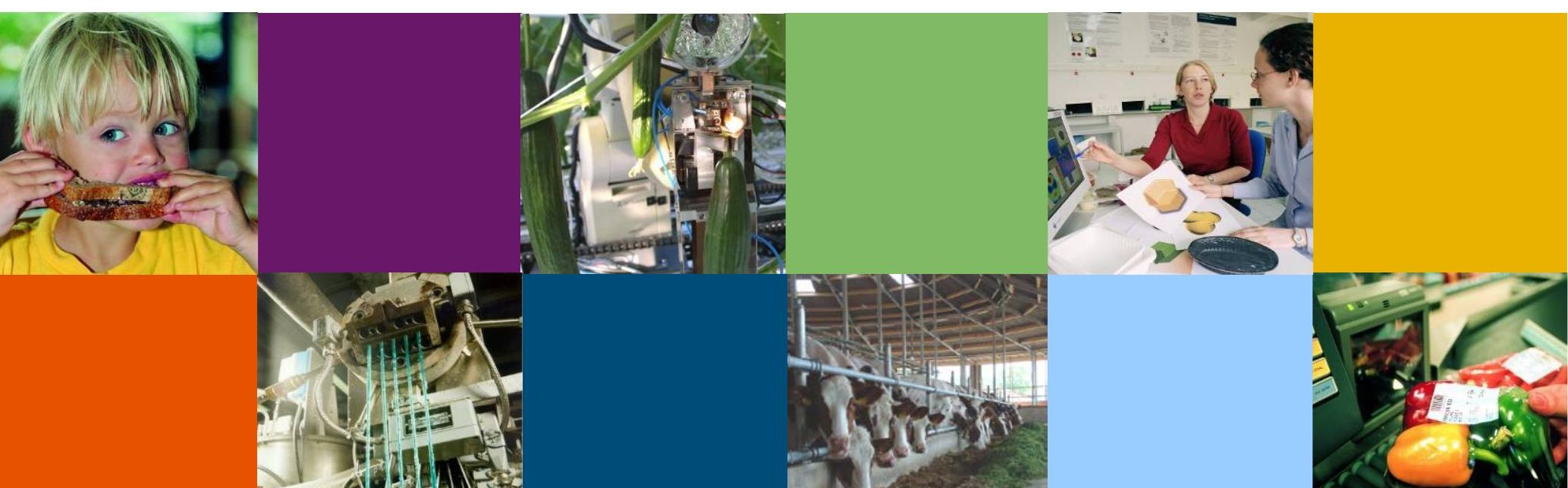




\section{Colophon}

Title

Author(s)

Number

ISBN-number

Date of publication

Confidentiality

Project number

Approved by
Analysis of shipments of cut tulips in 12 reefer containers

Dr. Leo Lukasse

1626

N/A

Febr. 2016

Yes, till three years after date of publication.

6239044900

Ir. Janneke de Kramer

Wageningen UR Food \& Biobased Research

P.O. Box 17

NL-6700 AA Wageningen

Tel: +31 (0)317480084

E-mail: info.fbr@wur.nl

Internet: www.wur.nl

(C) Wageningen UR Food \& Biobased Research, institute within the legal entity Stichting Dienst Landbouwkundig Onderzoek

All rights reserved. No part of this publication may be reproduced, stored in a retrieval system of any nature, or transmitted, in any form or by any means, electronic, mechanical, photocopying, recording or otherwise, without the prior permission of the publisher. The publisher does not accept any liability for inaccuracies in this report.

This report can be downloaded for free from February 2019 at https://doi.org/10.18174/563044 or at www.wur.nl/wfbr (under publications). 


\begin{abstract}
The aim of this study is to analyse the available data on 12 cut tulip shipments and, more generally, to evaluate the way of shipping cut tulips. The specified settings for all containers are Tset $=+0.5{ }^{\circ} \mathrm{C}$, RHset $=65 \%$ and Fresh Air Exchange $(\mathrm{FAE})=5 \mathrm{~m}^{3} / \mathrm{h}$. Available data include bills of lading, shipper's temperature recorders, survey reports and RCM unit downloads. The available data reveal freezing injury and subzero temperatures in multiple containers. In the discussion it is explained that the risk of freezing injury is inherent to the combination of load and unit settings.

It is concluded that the reported way of shipping cut tulips impairs temperature control by multiple mechanisms related to dehumidification, and the physical process of evaporative cooling which is activated due to dehumidification.

For future shipments the most important recommendation is to not specify a relative humidity set point, to use procona boxes to ship the tulips vertically and supply water-dissolved growth inhibitor $\mathrm{BVB}+$. Do not use more water than needed to dissolve the BVB+. Use the procona boxes for rehydration after arrival.
\end{abstract}




\section{Content}

$\begin{array}{ll}\text { Abstract } & 3\end{array}$

1 Introduction $\quad \mathbf{5}$

1.1 Aim 5

2 Summary of the available information $\quad 5$

2.1 recordings and damage in MNBU3297853 9

2.2 recordings in MNBU3326099 (no damage reported) 11

3 Discussion of observations 12

4 How humidity control impairs temperature control. 17

5 Conclusions 17

6 Recommendation for future shipments of cut tulip flowers $\quad 18$

$\begin{array}{ll}\text { References } & 18\end{array}$

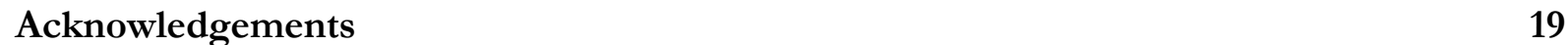




\section{Introduction}

Mr. Wim de Groot from Raetsheren van Orden (www.rhvo.nl) is involved as a shipper's insurer in the shipment of cut tulip flowers. In 2014 and 2015 he encountered a series of shipments in 12 Maersk Line reefer containers set at $+0.5^{\circ} \mathrm{C}$ where the shipper's temperature recorders recorded temperatures below set point. Three of them were involved in cargo claims, in all of them freezing injury was reported.

In May 2015 Wim de Groot asked Leo Lukasse of Wageningen UR Food \& Biobased Research to analyse the available data on these 12 cut tulip shipments and, more generally, to evaluate the way of shipping cut tulips.

On June 10, 2015 both Henrik Lindhardt (Maersk Line) and Wim de Groot (Raetsheren van Orden) confirmed by email to merely use this report as a means to increase insight, and not use it in settling open claims.

\subsection{Aim}

The aim of this study is to analyse the available data on these 12 cut tulip shipments and, more generally, to evaluate the way of shipping cut tulips.

Analysis is based on:

- Bills of lading (12).

- Shipper's Sensitech Temp'Tale4 recorders (3 per container) for temperature and relative humidity (RH) with $10 \mathrm{~min}$. datalog interval.

- Post calibration certificates for shipper's temperature recorders (available to 3 out of the 12 containers).

- Maersk Line's RCM downloads with respect to recorded temperature and RH (datalog interval 1 hour).

- K-services (www.kservices.org) survey reports no. 1721, 1783 and 1784 (covering 3 containers).

- $\quad$ www.reefertransport.nl (to relate container number to reefer unit type).

\section{Summary of the available information}

All shipments are from Bovenkarspel (NL) to Monroe NY (USA).

Normal transit time, from stuffing till unstuffing, is approx. 17 days.

Each shipment carries some 710 boxes (procona) of tulips, resulting in a payload of approx. 10,342 kg per container (Fig. 1, Fig. 2).

Shipper recorders are said to be positioned in front, middle and back, supposedly \pm on top of cargo.

Settings in all shipments are Tset $=+0.5^{\circ} \mathrm{C}$, RHset $=65 \%$ and Fresh Air Exchange $(\mathrm{FAE})=5$ $\mathrm{m}^{3} / \mathrm{h}$.

Table 1 lists all 12 containers involved, their unit type and the date they were shipped on board. 
Three out of the 12 containers concern claim cases. Some key elements in the information provided in the K-services survey reports on these three containers:

1. MNBU3183547 (K-services report no. 1783): 10 days delay in-transit on a trip that usually takes $10 \sim 12$ days. Observed damage: primarily dehydration (Fig. 4), especially at door-end; mould formed on foliage tips; some freezing injury at top tiers.

2. MNBU3297853 (K-services report no. 1784): 10 days delay in-transit on a trip that usually takes $10 \sim 12$ days. Observed damage: dehydration (especially at door-end), mould formed on foliage tips (Fig. 5), and freezing injury at top tiers.

3. MNBU3235511 (K-services report no. 1721): freezing injury (Fig. 3).

For the three claim containers Sensitech post validation certificates are provided for each of the shipper's recorders. According to the certificates all recorders pass the test.

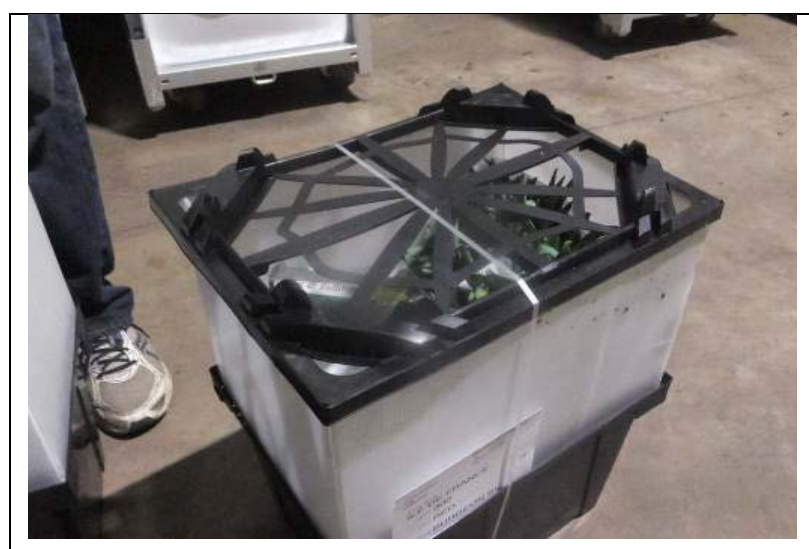

Fig. 1, box (procona) of cut tulip flowers.

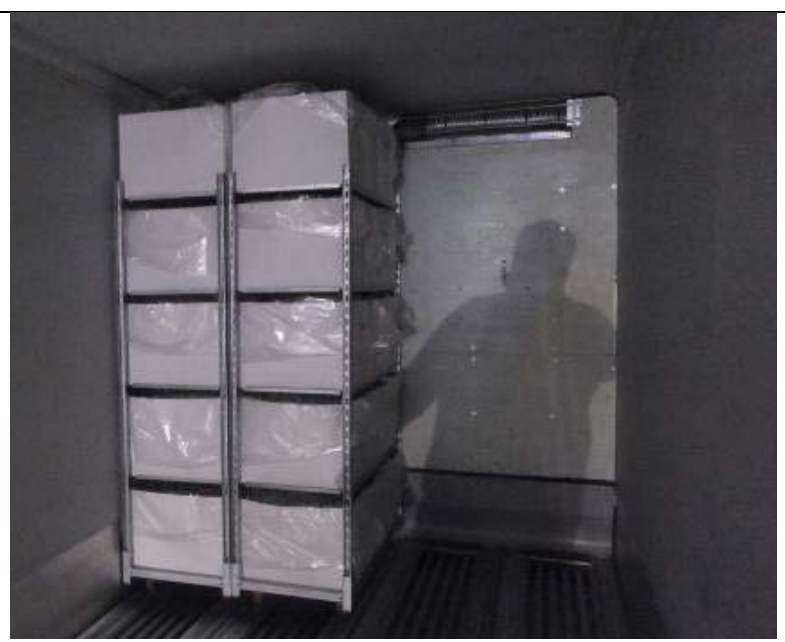

Fig. 2, boxes (procona's) of cut tulips organised in 5 tiers on metal frame farm carts (CC-carts).

Table 1, Analysis of Maersk Line downloads (in red the three for which cargo damage was claimed).

\begin{tabular}{|l|l|l|}
\hline container no. & unit type & date shipped on board \\
\hline MNBU0006506 & Carrier PrimeLine & $14-3-2015$ \\
\hline MNBU0087241 & Carrier PrimeLine & $14-3-2015$ \\
\hline MNBU3131585 & Starcool CIM6 & $23-3-2015$ \\
\hline MNBU3183547 & Starcool CIM6 & $6-4-2015$ \\
\hline MNBU3230675 & Starcool CIM6 & $23-3-2015$ \\
\hline MNBU3235511 & Starcool CIM6 & $19-4-2014$ \\
\hline MNBU3247512 & Starcool CIM6 & $10-4-2015$ \\
\hline MNBU3264295 & Starcool CIM6 & $14-4-2015$ \\
\hline MNBU3297853 & Starcool CIM6 & $6-4-2015$ \\
\hline MNBU3299178 & Starcool CIM6 & $10-4-2015$ \\
\hline MNBU3326099 & Starcool CIM6 & $10-4-2015$ \\
\hline MNBU9028018 & Starcool CIM6 & $8-3-2015$ \\
\hline
\end{tabular}




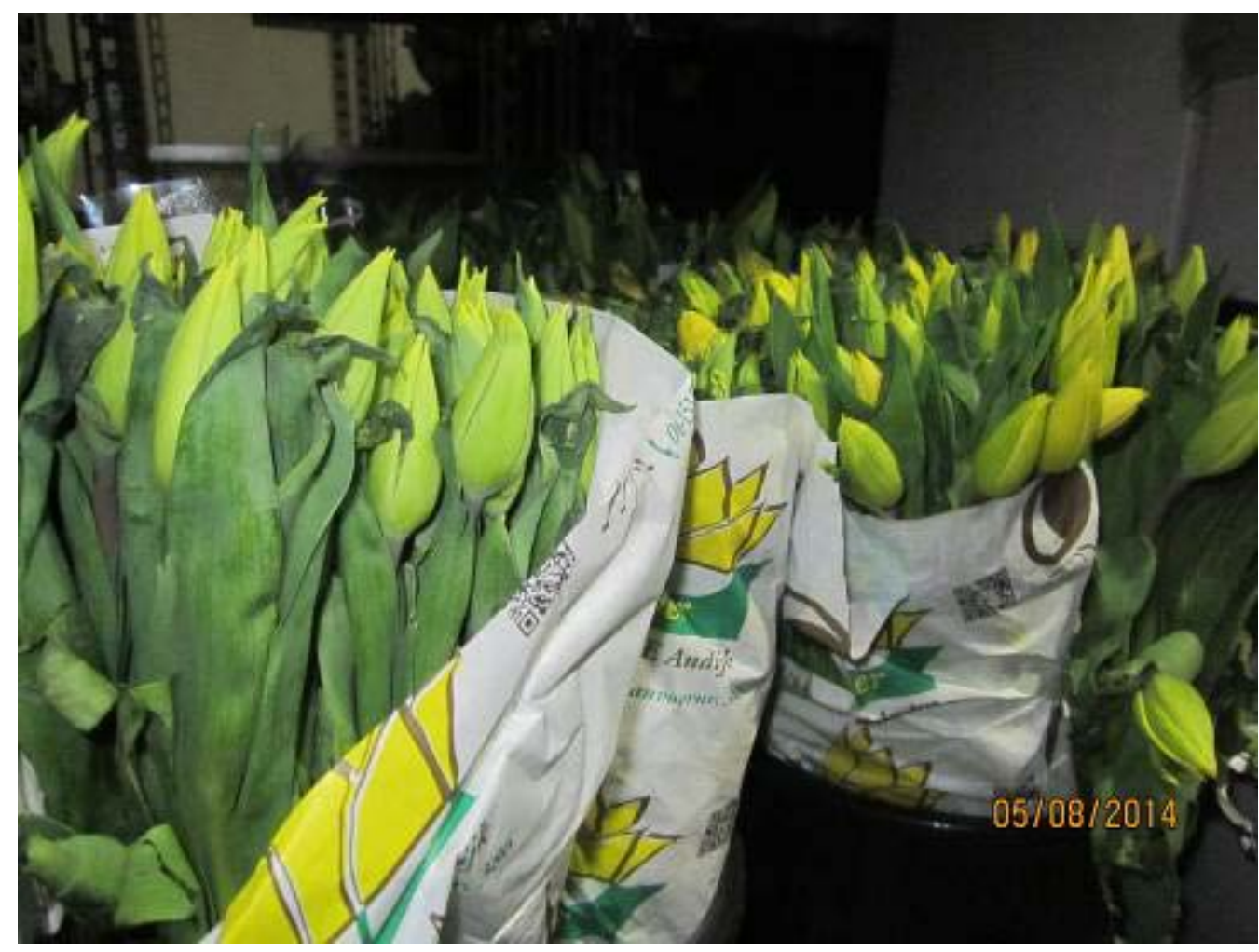

Fig. 3, freezing injury in MNBU3235511.

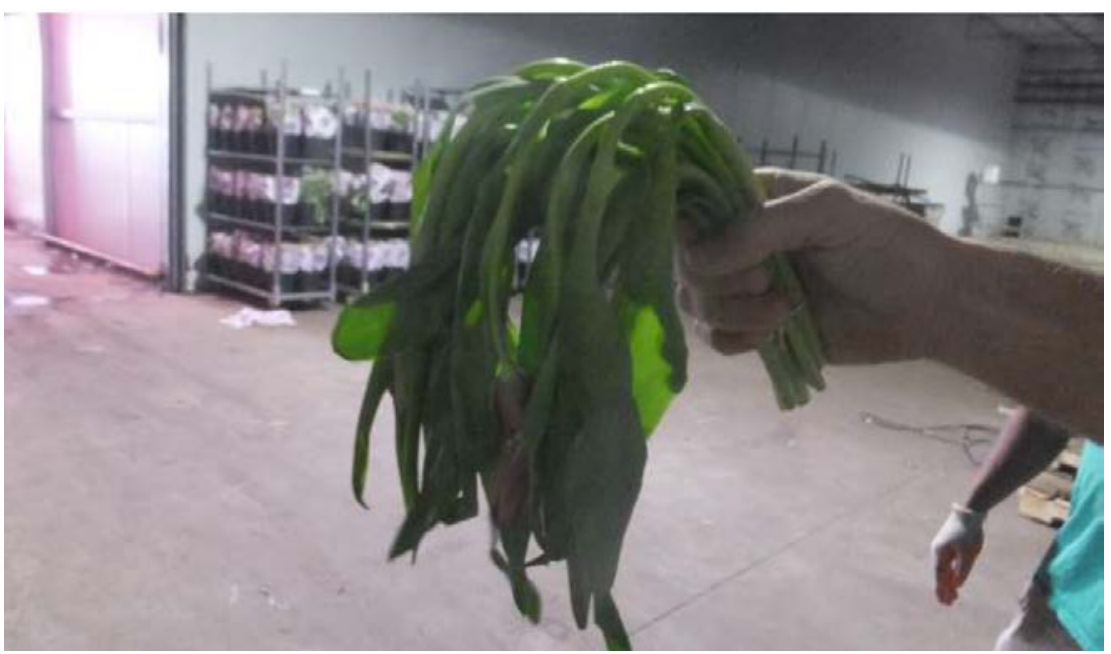

Fig. 4, dehydrated tulips delivered in MNBU3183547. 


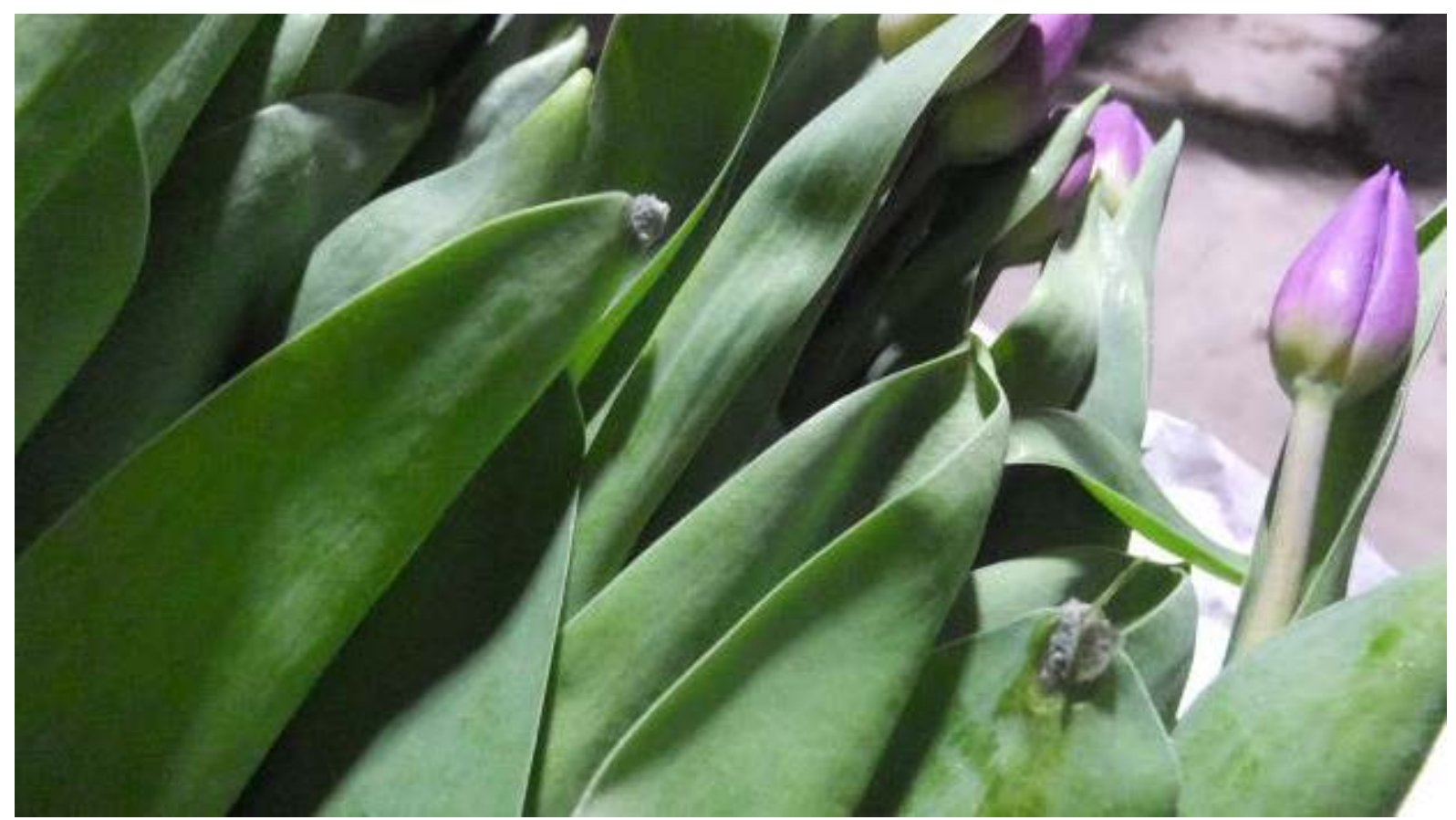

Fig. 5, mould on leaf tips delivered in MNBU3297853.

Section 2.1 presents all recordings and some photos of the damage found in MNBU3297853, one of the three claim containers. Section 2.2 presents all recordings for MNBU3326099. For this container MNBU3326099 no cargo claim was filed, and hence no survey report is available. For brevity the recordings for all the other containers are not shown, it would basically be more of the same. 
2.1 recordings and damage in MNBU3297853

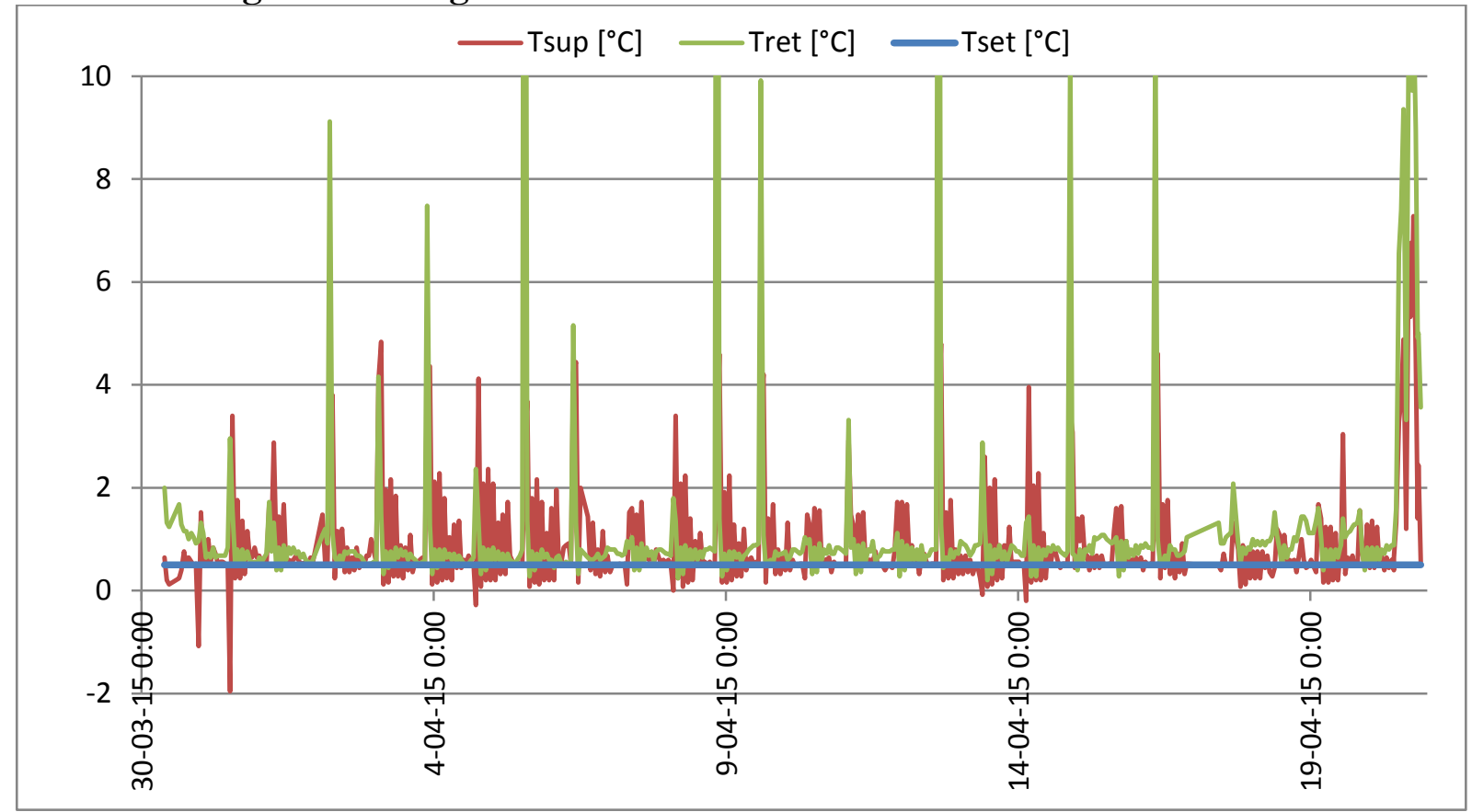

Fig. 6, MNBU3297853 reefer unit temperature data.

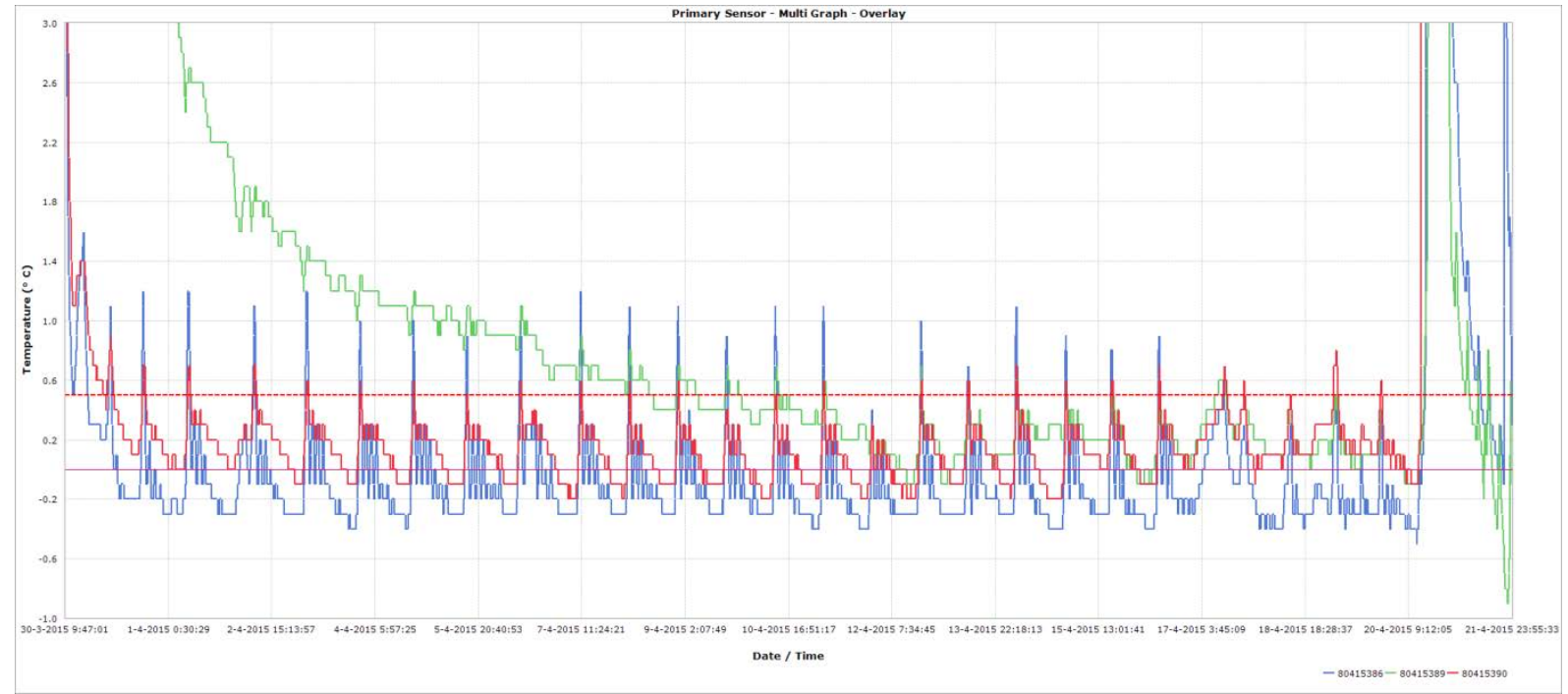

Fig. 7, MNBU3297853 shipper's temperature recorders. 


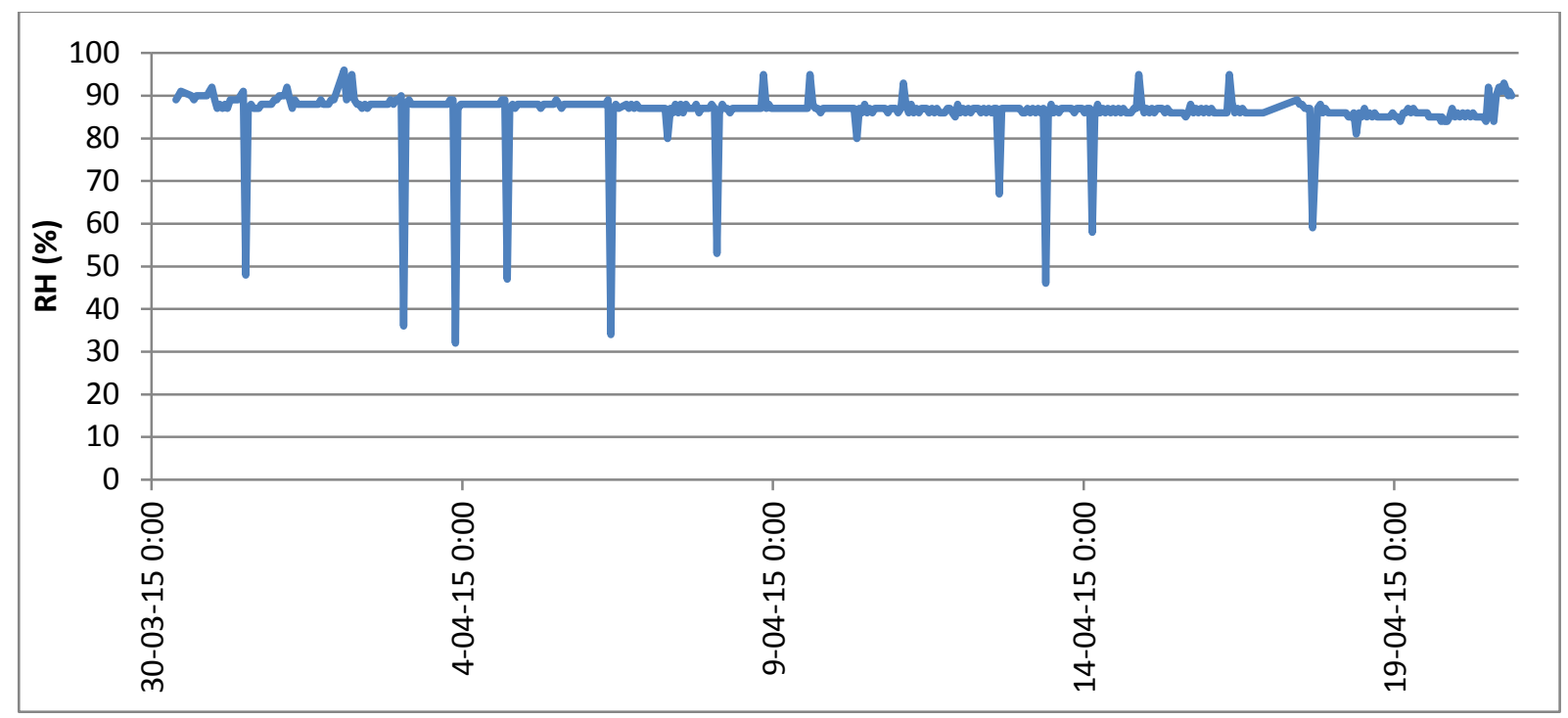

Fig. 8, MNBU3297853 reefer unit RH data.

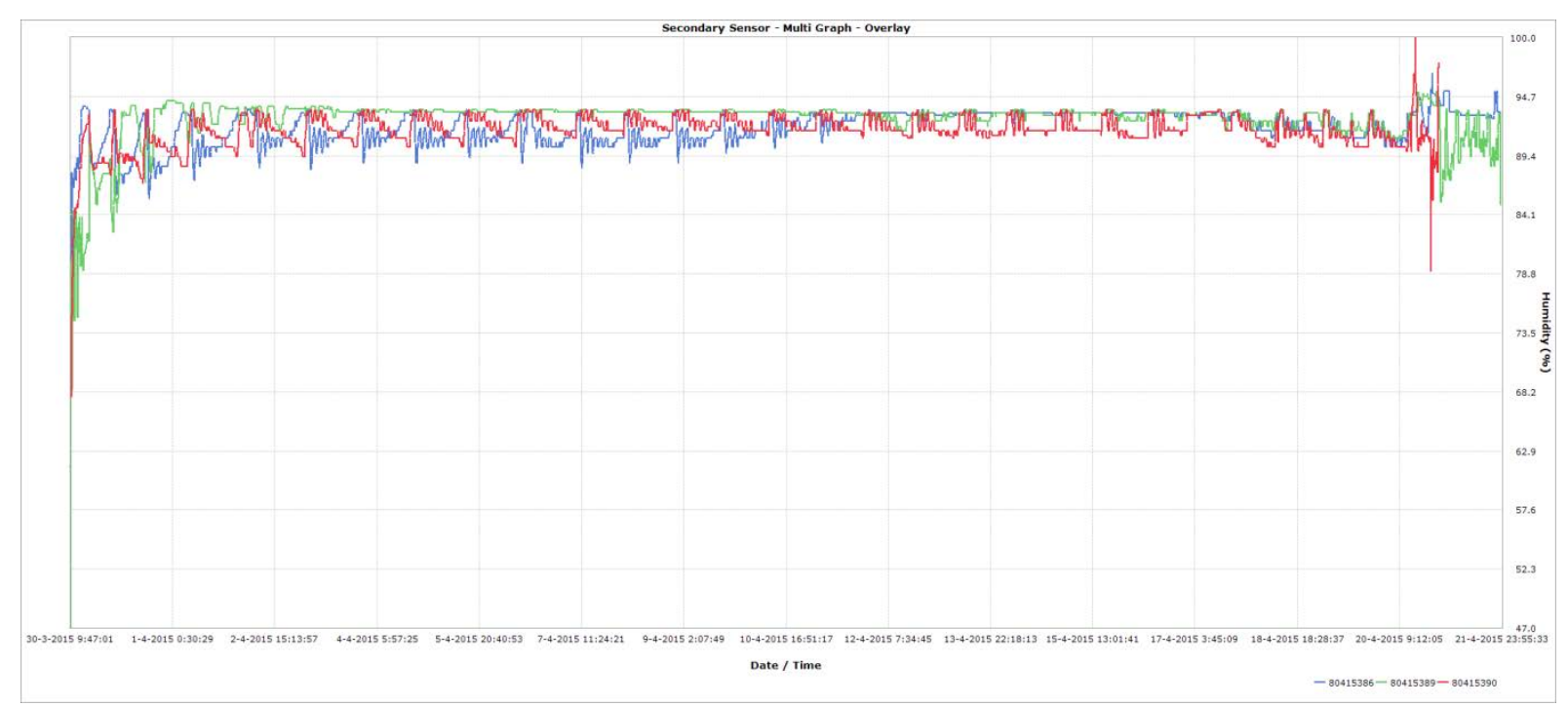

Fig. 9, MNBU3297853 shipper's RH recorders. 


\section{2 recordings in MNBU3326099 (no damage reported)}

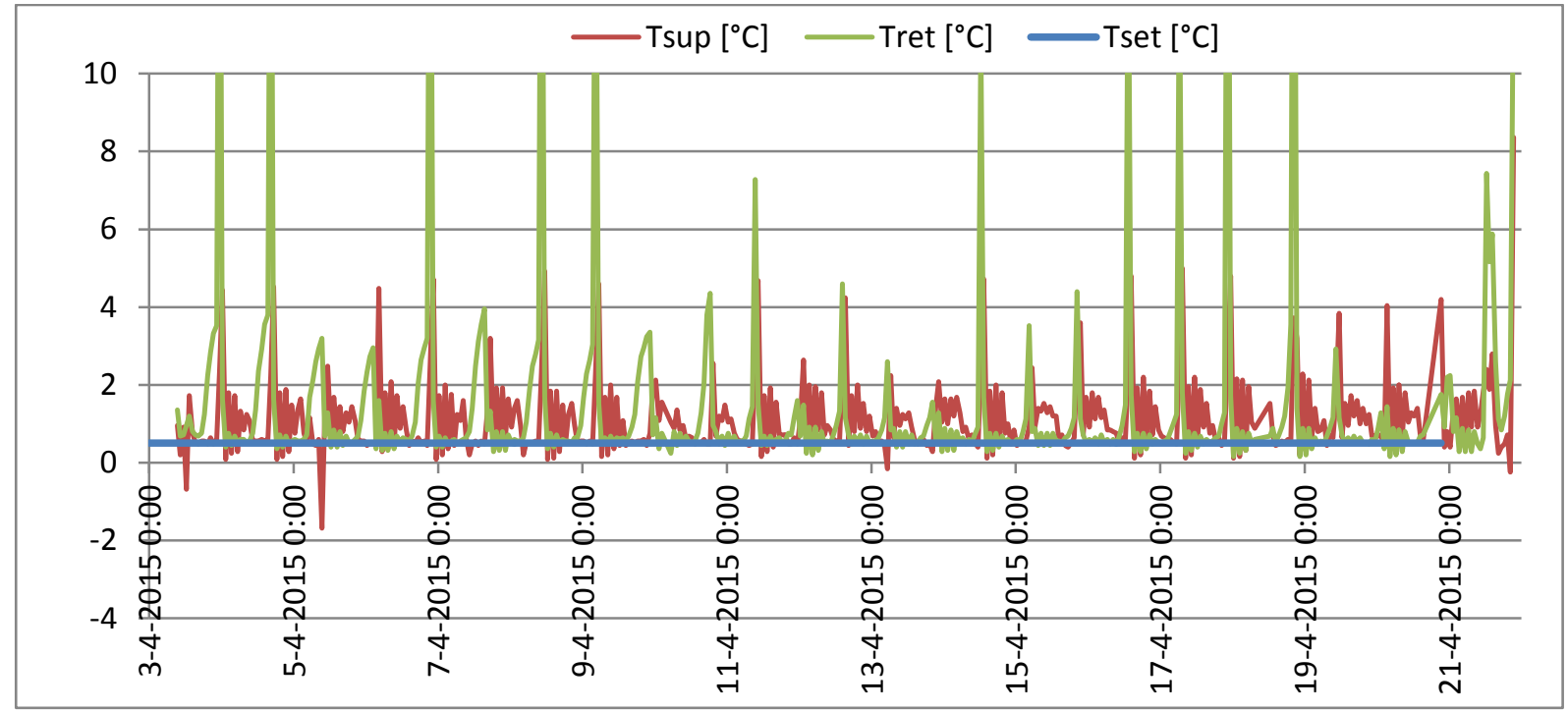

Fig. 10, MNBU3326099 reefer unit temperature data.

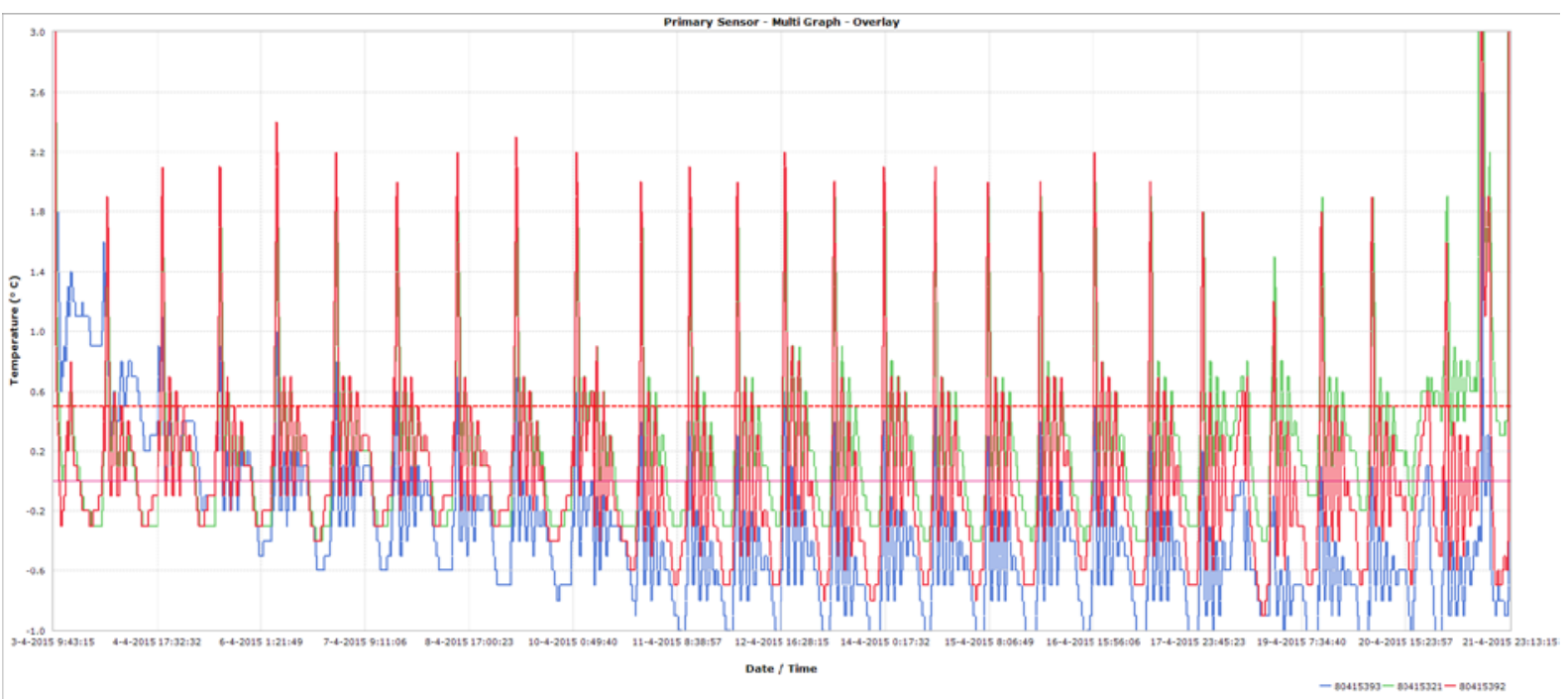

Fig. 11, MNBU3326099 - shipper's temperature recorders. 


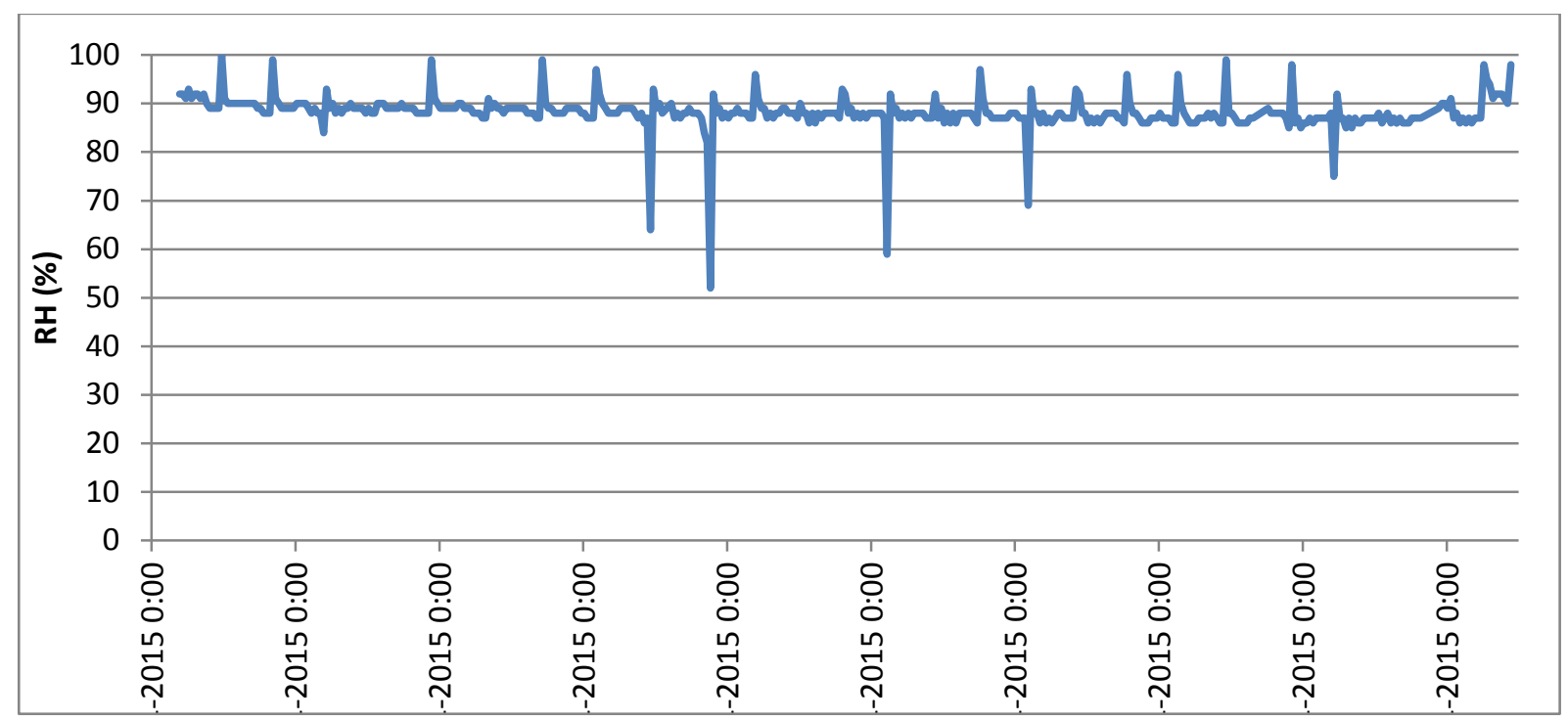

Fig. 12, MNBU3326099 reefer unit RH data.

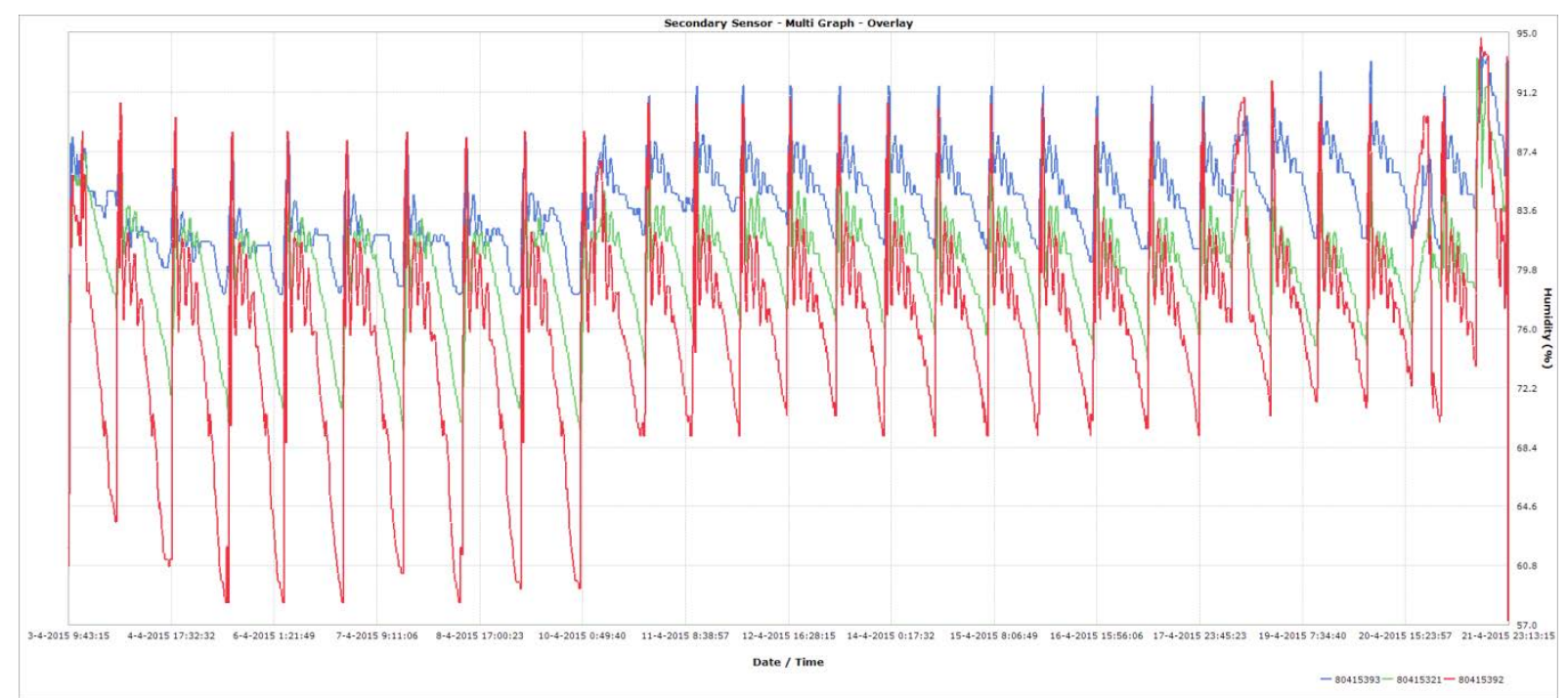

Fig. 13, MNBU3326099 - shipper's RH recorders.

\section{Discussion of observations}

It is interesting to note that MNBU3183547 and MNBU3297853 were surveyed because of the 10 days delay. For both of them some freezing injury was reported. Delays do not cause freezing injury. Recorded temperatures are similar in all 12 containers. The question therefore arises if some freezing injury occurs in each container.

All reefer unit downloads have been analysed (see Table 2). No malfunctions or significant offpower periods were observed. 
Table 2, Analysis of Maersk Line downloads (in red the three for which cargo damage was claimed).

\begin{tabular}{|c|c|c|c|}
\hline container no. & unit type & $\begin{array}{l}\text { date } \\
\text { shipped } \\
\text { on board }\end{array}$ & comments on unit download \\
\hline MNBU0006506 & $\begin{array}{l}\text { Carrier } \\
\text { PrimeLine }\end{array}$ & $14-3-2015$ & $\begin{array}{l}\text { Tset }=+0.5^{\circ} \mathrm{C} . \text { Temperature control pattern is } \\
\text { Quest-for-Carrier. Quest-for-Carrier is active both } \\
\text { with an without RH setting, so there's no proof if } \\
\text { RH control has been set. Averaged over time Tret } \approx \\
\text { Tsup }+0.5^{\circ} \mathrm{C} \text {, not unusual in normal temperature- } \\
\text { control shipments. }\end{array}$ \\
\hline MNBU0087241 & $\begin{array}{l}\text { Carrier } \\
\text { PrimeLine }\end{array}$ & $14-3-2015$ & $\begin{array}{l}\text { Tset }=+0.5{ }^{\circ} \mathrm{C} . \text { Temperature control pattern is } \\
\text { Quest-for-Carrier. Quest-for-Carrier is active both } \\
\text { with an without RH setting, so there's no proof if } \\
\text { RH control has been set. During the first hours } \\
\text { after defrost Tret }<\text { Tsup (especially visible from } 16 \\
\text { till } 20 \text { March '15), this is a typical effect of } \\
\text { evaporative cooling. }\end{array}$ \\
\hline MNBU3131585 & $\begin{array}{l}\text { Starcool } \\
\text { CIM6 }\end{array}$ & $23-3-2015$ & $\begin{array}{l}\text { Tset }=+0.5{ }^{\circ} \mathrm{C} . \text { Temperature control pattern is } \\
\text { non-Quest, so }{ }^{1} \mathrm{RH} \text { has been set. Tsup }=\text { Tset. Right } \\
\text { after a defrost Tret } \approx \text { Tsup, then Tret gradually rises } \\
\text { till approx. Tsup }+0.8{ }^{\circ} \mathrm{C} \text { just prior to next defrost. } \\
\text { This is normal. }\end{array}$ \\
\hline MNBU3183547 & $\begin{array}{l}\text { Starcool } \\
\text { CIM6 }\end{array}$ & $6-4-2015$ & download not received \\
\hline MNBU3230675 & $\begin{array}{l}\text { Starcool } \\
\text { CIM6 }\end{array}$ & $23-3-2015$ & $\begin{array}{l}\text { Tset }=+0.5{ }^{\circ} \mathrm{C} . \text { Temperature control pattern is } \\
\text { non-Quest, so }{ }^{1} \mathrm{RH} \text { has been set. Tsup } \approx \text { Tret } \approx \\
\text { Tset. This looks normal. }\end{array}$ \\
\hline MNBU3235511 & $\begin{array}{l}\text { Starcool } \\
\text { CIM6 }\end{array}$ & $19-4-2014$ & download does not cover period of interest \\
\hline MNBU3247512 & $\begin{array}{l}\text { Starcool } \\
\text { CIM6 }\end{array}$ & $10-4-2015$ & download not received \\
\hline MNBU3264295 & $\begin{array}{l}\text { Starcool } \\
\text { CIM6 }\end{array}$ & $14-4-2015$ & download not received \\
\hline MNBU3297853 & $\begin{array}{l}\text { Starcool } \\
\text { CIM6 }\end{array}$ & 6-4-2015 & $\begin{array}{l}\text { See Fig. } 6 \text { and Fig. } 7 \text {. Tset }=+0.5^{\circ} \mathrm{C} . \text { Temperature } \\
\text { control pattern is non-Quest, so }{ }^{1} \mathrm{RH} \text { has been set. } \\
\text { Tsup } \approx \text { Tret } \approx \text { Tset. This looks normal. }\end{array}$ \\
\hline MNBU3299178 & $\begin{array}{l}\text { Starcool } \\
\text { CIM6 }\end{array}$ & $10-4-2015$ & download not received \\
\hline
\end{tabular}

1. By default Starcool CIM6 controls temperature according to Quest II logic, but that changes to non-Quest when RH is set. Hence the temperature control pattern tells whether or not RH has been set. 


\begin{tabular}{|l|l|l|l|}
\hline container no. & unit type & $\begin{array}{l}\text { date } \\
\text { shipped } \\
\text { on board }\end{array}$ & comments on unit download \\
\hline MNBU3326099 & Starcool & $10-4-2015$ & $\begin{array}{l}\text { See Fig. } 10 \text { and Fig. } 11 . \text { Tset }=+0.5^{\circ} \mathrm{C} . \\
\text { Temperature control pattern is non-Quest, so RH } \\
\text { has been set. From April } 4 \text { (trip start) till April } 10 \\
\text { Tret rises till approx. } 3.0^{\circ} \mathrm{C} \text { prior to defrosts } \\
\text { (defrosts come a little late). After April } 14 \text { between } \\
\text { defrosts mostly Tret }=\text { Tset, while Tsup } \approx \text { Tret }+ \\
1.0{ }^{\circ} \mathrm{C}, \text { this is a typical effect of evaporative cooling. }\end{array}$ \\
\hline MNBU9028018 & Starcool & $8-3-2015$ & $\begin{array}{l}\text { Tset }=+0.5^{\circ} \mathrm{C} . \text { Temperature control pattern is } \\
\text { non-Quest, so } \mathrm{RH} \text { has been set. Between defrosts } \\
\text { mostly Tret }=\text { Tset, while Tsup } \approx \text { Tret }+1.0{ }^{\circ} \mathrm{C}, \text { this } \\
\text { is a typical effect of evaporative cooling. }\end{array}$ \\
\hline
\end{tabular}

Is there an effect of unit type? That's not visible in the data. The data cover two Carrier PrimeLine units and ten Starcool CIM6 units. There's no structural difference in the data collected from these two types of reefer units.

To the best of the author's knowledge reefer unit sensors for temperature and $\mathrm{RH}$ are never calibrated. In the PTI (Pre-Trip Inspection) there is a probe check procedure, which mutually compares all sensors for return air temperature and supply air temperature. The probe check procedure consists of running only the evaporator fans for up to eight minutes in order to mutually compare the readings from the temperature probes. Carrier Transicold, the leading unit manufacturer, deems its supply air temperature sensors valid in case the mutual difference is less than $0.5^{\circ} \mathrm{C}$ during this test (anonymous, 2014). General consensus in the industry with respect to sensor accuracy is that supply - and return air temperature sensors report the true temperature \pm $0.25^{\circ} \mathrm{C}$. Starcool claims an accuracy of $\pm 0.15^{\circ} \mathrm{C}$ (anonymous, 2015). After dozens of reefer container climate chamber tests the author has the impression that the unit's temperature sensors usually meet the $\pm 0.25^{\circ} \mathrm{C}$ accuracy indeed.

The Sensitech post validation certificates do not list sensor's trip numbers, while the author only has the sensor's trip numbers. Hence, these certificates cannot be related to individual sensors. All Sensitech post validation certificates conclude that the calibrated sensors pass the validation. The 'pass' conclusion is only possible by the grace of the large published tolerances of $0.55 \sim 1.11$ ${ }^{\circ} \mathrm{C}$. The fact is that all certificates report sensor readings $0.3 \sim 1.1{ }^{\circ} \mathrm{C}$ colder than the measured reference temperature, indicating that all recorders report $0.3 \sim 1.1^{\circ} \mathrm{C}$ too cold temperatures. 
The shipper's temperature recorders (e.g. Fig. 7, Fig. 11) drop to levels well below set point and those registered by the reefer units. Unfortunately their value is not too reliable in view of the preceding paragraph. But Fig. 11 shows measured temperatures more than $1.5^{\circ} \mathrm{C}$ colder than set point, that is a deviation distinctly bigger than the ones reported in the calibration certificates. Moreover, why do temperatures in Fig. 11 after April 10 drop to approx. $0.5^{\circ} \mathrm{C}$ lower than before that date?

The shipper's temperature recorders (e.g. Fig. 7, Fig. 11) exhibit a typical \pm 12 hour periodicity. The periodicity equals the defrost interval automatically chosen by the reefer unit controller's auto-defrost (see how defrost spikes in Fig. 10 and Fig. 11 coincide). As a reference: in 'usual' chilled-mode reefer shipments the auto-defrost interval is larger than 48 hour, hence a 12 hour defrost interval is very short. It indicates a high rate of frost formation on the evaporator. That is no surprise: water easily evaporates from the tulips, while the unit is trying to maximally extract moisture from the air to reach the $65 \% \mathrm{RH}$ set point.

The recorded $\mathrm{RH}$ is mostly above $80 \%$ for all recorders. Note that the reefer unit records its $\mathrm{RH}$ directly behind the return air grid. Clearly the unit lacks the dehumidification capacity to reduce $\mathrm{RH}$, measured in the return air flow, to the set $65 \%$ in this wet cargo. This is primarily because of the overwhelmingly large rate of evaporation from the tulips. Based on knowledge collected in other projects the author assumes that the supply air during the trips has likely been around +0.5 ${ }^{\circ} \mathrm{C}$ and $50 \% \mathrm{RH}$.

If water evaporates from a wet surface, that surface's temperature becomes colder than the (dry bulb) temperature of the air flowing over it. This is the phenomenon of evaporative cooling. The coldest possible surface temperature is the wet bulb temperature. Air of $0.5^{\circ} \mathrm{C}$ dry bulb temperature and $50 \% \mathrm{RH}$ has wet bulb temperature $-2.5^{\circ} \mathrm{C}$. In shipments of leafy plants, especially when placed in crates with free water, this process may/will occur: lots of water available, and lots of leaf surface area from which evaporation can take place. As an example see the readings (Fig. 14) taken by the author in the load shown in Fig. 15: the load temperatures (USDA) and return air temperature are distinctly colder than supply air temperature due to evaporative cooling at Tset $=16{ }^{\circ} \mathrm{C}$ and $\mathrm{RHset}=65 \%$.

Evaporative cooling especially occurs where air flow rate is highest. For this type of packaging (Fig. 1, Fig. 2) that means: at the top of the stems, where the leaf tips and flower buds are. 


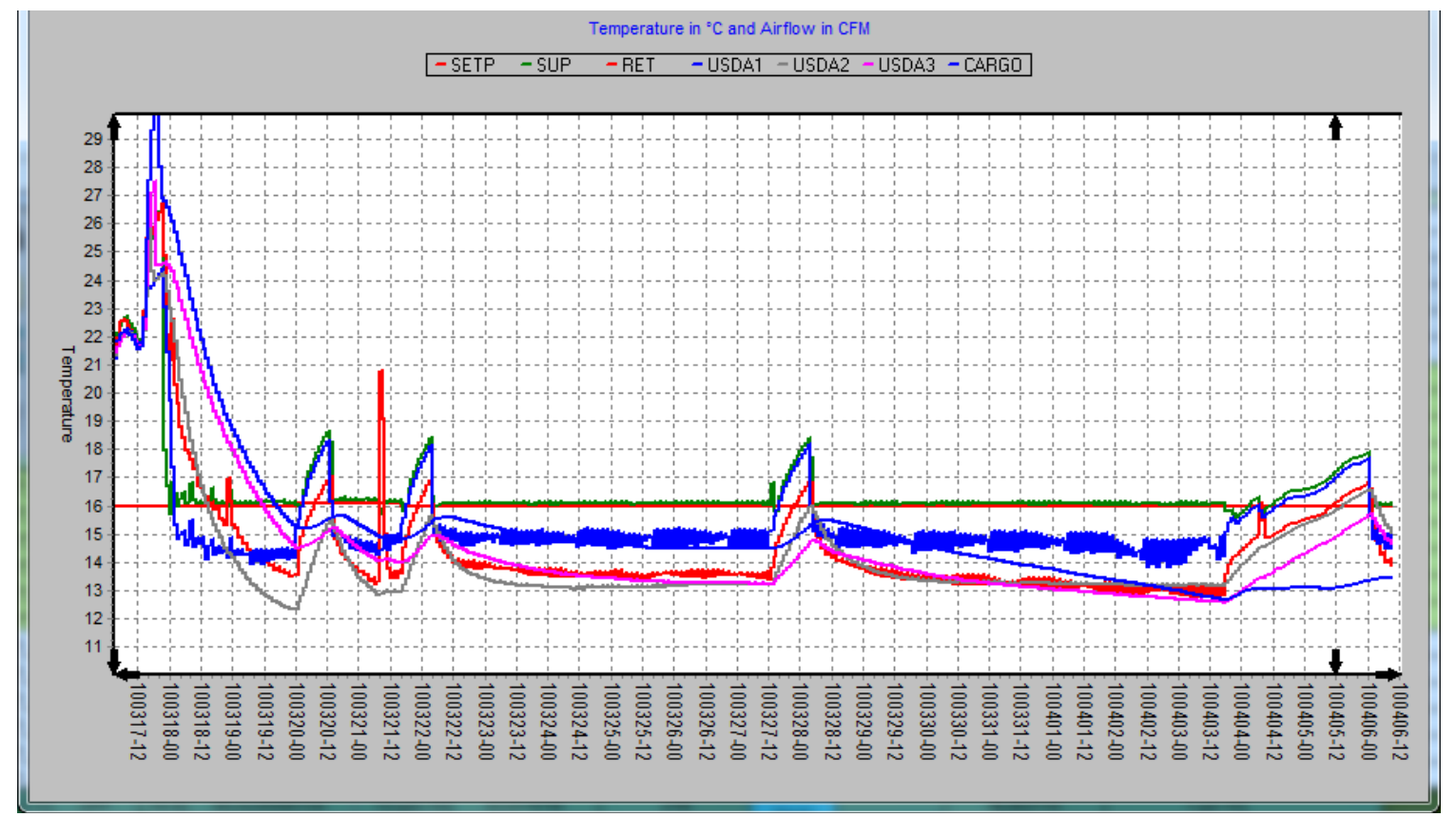

Fig. 14, temperatures well below set point due to evaporative cooling in a shipment of palms.

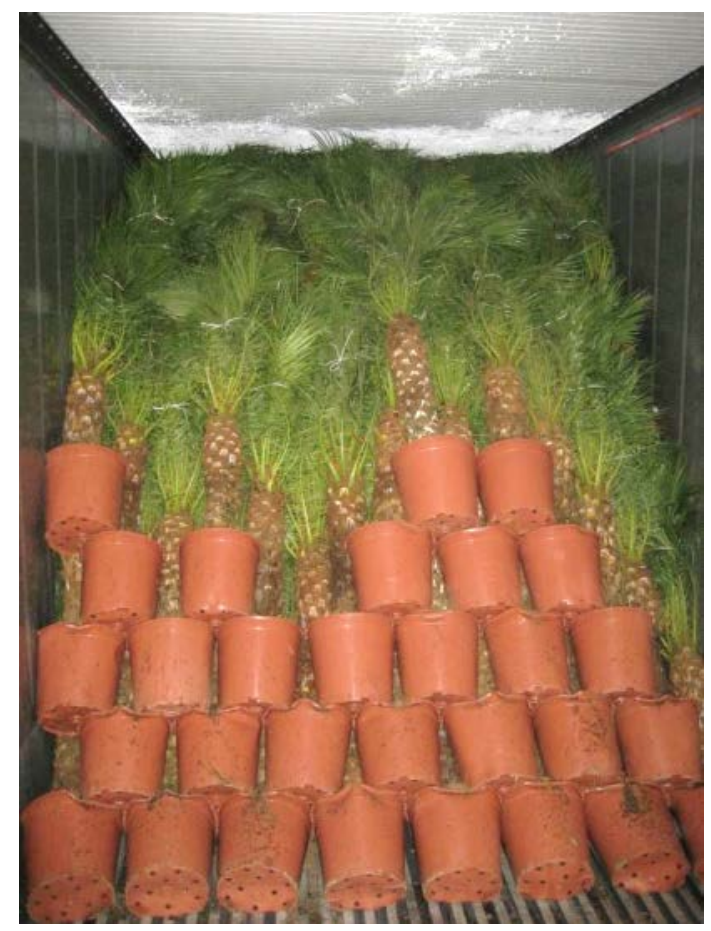

Fig. 15, 'packaging' and stowage of a shipment of palms.

Is the observed freezing injury caused by evaporative cooling? A reliable indicator of evaporative cooling in the load is when Tret $<$ Tsup. That indication is mildly present in some of the unit downloads (Fig. 10). Therefore the data do indicate that evaporative cooling has contributed to the freezing injury. 
Fig. 10 and Fig. 11 show both the reefer unit temperature data and the shipper's temperature recorder. It is worth noticing that the slightly late defrost starts (Fig. 10) from April 4 till April 10 have no visible impact on shipper's temperature recorders. The signs of evaporative cooling visible in Fig. 10 (periods where Tsup > Tret) are strongest in the period where shipper's temperature recorders record the lowest temperatures.

Skewed frosting of the evaporator coil is known to deteriorate the left-right differences in supply air temperature. Is the freezing injury caused by skewed frosting of the evaporator coil as a consequence of fresh air exchange (FAE)? This is not likely, because FAE is only set at $5 \mathrm{~m}^{3} / \mathrm{h}$. Moreover in April the ambient temperature on the route NL - New Ark is only $0 \sim 20{ }^{\circ} \mathrm{C}$ (as recorded in some of the unit downloads), and therefore the absolute humidity of ambient air is relatively low.

Is the freezing injury caused by cross-sectional differences in supply air temperature due to other causes than FAE? This is a possible factor. In earlier projects the author has seen instances where activating dehumidification deteriorated the left-right differences in supply air temperature. The reefer unit measures supply air temperature in just one spot, and will not register these gradients.

\section{How humidity control impairs temperature control.}

Regardless of the load, activating dehumidification deteriorates temperature control in multiple ways:

1. Door-end temperatures deviate more from unit-end temperatures because the unit (periodically) reduces evaporator fan speed and because more frost accumulates on the evaporator.

2. Dehumidification necessitates more frequent defrosting, resulting in more (defrost) periods during which there is no air circulation and a spike in return air temperature.

3. Dehumidification may worsen left-right distribution in the supply air temperature. That distribution will not be recorded in the unit's measured supply air temperature.

An extra complication when applying dehumidification to wet loads with relatively large surface areas (cut flowers):

4. Evaporative cooling may cool the product to the wet bulb temperature of the supply air, which is multiple ${ }^{\circ} \mathrm{C}$ below supply air temperature.

\section{Conclusions}

The reported way of shipping cut tulips impairs temperature control by multiple mechanisms related to dehumidification, and the physical process of evaporative cooling which is activated due to dehumidification. The risk of freezing injury is inherent to the combination of flowers on water, a temperature set point of $+0.5^{\circ} \mathrm{C}$ and setting a humidity set point. 


\section{Recommendation for future shipments of cut tulip flowers}

A simple way to achieve significantly tighter temperature control is to switch off dehumidification, i.e. to not specify a RH set point.

It is known that many cut tulip cultivars can be shipped at $+0.5^{\circ} \mathrm{C}$ for up to 20 days with only some water to dissolve growth inhibitor BVB+ (see e.g. Harkema \& Mensink, 2005). Therefore it is recommended to not specify a relative humidity set point, use procona boxes to ship the tulips vertically and supply water-dissolved growth inhibitor BVB+ (http://www.chrysal.com/int/Home/Products/Post-harvest-Treatments/Chrysal-BVBPlus.html). Do not use more water than needed to dissolve the BVB+. Expect the BVB+ solution to run out before or in the early stage of the transport. Use the procona boxes for rehydration after arrival.

To limit mould growth it may help to use packaging materials and a stowage pattern allowing some air flow through the bunches of flowers instead of setting an RH set point.

If it is decided to stick with dehumidification, then consider to raise the temperature set point to create a larger margin between set point and the freezing limit. That larger margin is needed in view of the less accurate temperature control during dehumidification and the unpredictable contribution of evaporative cooling.

It looks like Fresh Air Exchange can be closed, because the currently used $5 \mathrm{~m}^{3} / \mathrm{h}$ of fresh air exchange apparently suffices, and is negligible, and is in the same order of magnitude of the natural fresh air exchange due to container air leakage. A quote from ISO1496-2 (1996): 'for all thermal containers ... the air leakage rate, expressed in standard atmospheric conditions, shall not exceed $10 \mathrm{~m}^{3} / \mathrm{h}$.'

\section{References}

Anonymous (2015). Operating and service manual - Star Cool CIM6 refrigeration unit Model SCU-20/40 and SCI-20/40. Available from

http://www.mcicontainers.com/Service/Downloadmanualscatalogs/Pages/Downloadmanualsc atalogs.aspx.

Anonymous (2014). T-362: OPERATION AND SERVICE MANUAL CONTAINER

REFRIGERATION UNIT - Model 69NT40- 561- 200 to 299. Available from http://www.carrier.com/container-refrigeration/en/worldwide/service-support/\#2

Harkema H., Mensink M.G.J. (2005). Zeetransport van snijbloemen: "if we get this quality more, we will sell a lot". Wageningen UR - Food \& Biobased Research report no. 459. Available from http://edepot.wur.nl/297974 (in Dutch).

ISO1496-2 (1996). ISO1496-2 series 1 freight containers - specification and testing - part 2: thermal containers. 4th edition.

K-services survey report 1721.

K-services survey report 1783.

K-services survey report 1784. 


\section{Acknowledgements}

The author is grateful to Maersk Line for financial support of this study. The author thanks

Raetsheren van Orden, represented by Mr. Wim de Groot, and Maersk Line, represented by Mr.

Henrik Lindhardt, for their kind cooperation. 